\title{
STAKEHOLDER AND VISITOR REFLECTIONS OF SPORT BRAND POSITIONING IN SOUTH AFRICA
}

\author{
Janice HEMMONSBEY \\ Cape Peninsula University of Technology, Department of Sport Management, South Africa, e-mail: HEMMONSBEYJ@cput.ac.za \\ Tembi M. TICHAAWA* \\ University of Johannesburg, College of Business and Economics, School of Tourism and Hospitality, South Africa, e-mail: tembit@uj.ac.za
}

\begin{abstract}
Citation: Hemmonsbey, J., \& Tichaawa, T.M. (2021). STAKEHOLDER AND VISITOR REFLECTIONS OF SPORT BRAND POSITIONING IN SOUTH AFRICA. GeoJournal of Tourism and Geosites, 34(1), 177-185. https://doi.org/10.30892/gtg.34123-634

Abstract: The purpose of this paper was to identify stakeholder and visitor perceptions of brand images of the South African destination brand in order to examine how sport is utilised as a catalytic agent for achieving brand positioning. Following a mixed method approach, in-depth semistructured interviews were conducted with 24 sport, tourism, and government stakeholders. Survey questionnaires were administered with 403 sport event visitors at major events across South Africa. The results show congruence between stakeholder and sport event visitor perceptions on the multi-layered brand images of South Africa. Uniquely defined city brand images raise challenges and opportunities for establishing a coherent national brand positioning. The utilisation of sport for brand positioning is greatly dependent on brand distinctiveness and dedicated stakeholder vision and policy. The study provides a framework of recommendations that practically guide key industry stakeholders on value propositions that underpin brand positioning strategies. This study also makes a contribution to existing brand positioning theories and practice by exploring the value proposition construct to a unique sport environment while employing real-life destination brand scenarios.
\end{abstract}

Key words: sport brand positioning, positioning strategy, sport events, stakeholder reflections, the South African brand

\section{INTRODUCTION}

Among scholars and practitioners, the development of alternative marketing strategies designed to satisfy the needs of specific target markets provided the initial spark of interest in the concept of brand positioning for place brands (Ibrahim and Gill, 2005). Therefore, the significance of brand positioning has been increasingly emerging in the place branding discourse and policy mandates of places. More specific to destination brands, it has been consistently proven that sport can be a catalyst for the re-branding of cities and nations. In particular to establishing tourism destinations, city planners and decision-makers spend millions of dollars on major sport events, including investing in sport business opportunities (Maennig, 2019). This is not only to draw on (new) sport tourism markets but to augment a favourable climate for establishing positive brand positioning (Herstein and Berger, 2013). Fuchs and Diamantopoulos (2012) are of the view that brand positioning emanates from consumer perceptions and therefore, positioning strategies are based on the examination of visitor perceptions and preferences. For this reason, marketers have limited control over product/ brand positioning. Strategies designed from an organisations' perspective, instead of the consumer perspective, are thus likely to be unsuccessful (Brooksbank, 1994).

Certainly, brand positioning as it applies to destinations involves complexities in its conceptualisation and practical features which suggest that the design and implementation of brand positioning strategies are not trivial (Insch, 2014). Despite the many complexities involved, and similarly to traditional marketing, stakeholders of tourism destinations should examine the perceptual images of the destination brand in line with developing positioning strategies. It is however still unclear how sport events - one of the biggest tourism niche industries - contribute to the awareness and perceptions of tourists on host destinations and, subsequently, how such perceptions inform brand positioning strategies. This ostensibly necessitates the current study purpose: to determine the perceptions of both consumers of sport (sport tourists) as the key perceptual entities of the destination brand, as well as the perceptions of stakeholders of sport and destination branding as the custodians of brand positioning strategies. Having successfully hosted a series of mega-events, including the 2010 FIFA World Cup (the first for an African country), as well as serving as host to a series of annual sport events, the South African destination brand was investigated.

The paper begins with a critical review on brand positioning literature and contextualises it to destination branding, with a particular focus on sport. Thereafter, the methodological processes and approaches are discussed according to a mixed methods research design. The key findings and discussion, which highlight implications to branding theories and stakeholder policies and practices are presented next. Thereafter, the paper concludes with recommendations for future research.

\section{LITERATURE REVIEW}

\section{Brand positioning in context to destinations}

Several studies have addressed topics related to the brand positioning of tourist destinations. Some studies have investigated the context of brand image (Daye, 2010; Raid, 2016; Klein, Völckner et al., 2019), while others have investigated brand identity as a key construct to brand positioning (Cai, 2002; Kapferer, 2002, Konecnik and Go, 2008; Bregoli, 2011). In fact, it is proposed by Kotsi and Pike (2020) that, in the tourism literature, Cai (2002) was the first to highlight the importance of brand identity development for destination $\mathrm{s}$ in order for marketing communications to achieve differentiation from their rival counterparts. Thus, both brand image- the subjective and perceptual phenomenon that is formed through consumer interpretation which is influenced by reasoning and/or emotions (Fuchs and Diamantopoulos, 2012) - and brand identity- the detailed and useful information about the brand, such as trademarks, logos, and strategic missions (Janiszwska and Insch, 2012; Lee Kim and Won, 2018) are essential elements for brand differentiation. To this end, Crawford and Di Benede tto (2008) propose that brand positioning is the attempt to create, change or foster specific images about a brand in the minds of consumers. In doing so, successful positioning creates brand preferences which influence consumer decisions when choosing specific brands over their competitors (Tasci and Gartner, 2007; Lee et al., 2018). Fuchs and Diamontoploulos (2010) further argue that brand positioning leads to a high level of

\footnotetext{
* Corresponding author
} 
brand equity and customer loyalty. The literature highlights that, achieving greater brand equity equates to achieving competitive advantage (Pike and Page, 2014). This is particularly important for tourist destinations that offer similar tourism products and possess comparable destination characteristics. In consideration of the foregoing, emerging literature focusses on the empirical investigation of brand equity based on consumer satisfaction and travel (re-visit) intentions (Chi, et al., 2020; Indrie et al., 2020; Tran et al., 2020).

Furthermore, Kapferer (2012) argues the importance of destinations to possess a clear value proposition to establish and augment brand distinctiveness. Consequently, many destinations have viewed sport (events) as powerful tools for brand positioning (Govers and Go, 2009; Zhang and Zhao, 2009; Hemmonsbey and Knott, 2016; Hemmonsbey and Tichaawa, 2019a/b; Hemmonsbey and Tichaawa, 2020). Accordingly, studies contextualising sport brand positioning in relation to consumer perceptions and tourist behaviour have emerged (Lee et al., 2018), thus giving grounds to the current study's scope and context. Destinations are the centrepiece of tourism; therefore, authorities are able to distinguish tourism destinations from similar destinations by positioning their unique and competitive attributes which make it a more attractive destination to visit (Chacko and Marcell, 2008). However, it can be challenging for destinations to select an appropriate frame of reference that defines its brand since destinations are comprised of a multiplicity of products that make up the destination brand (Saqib, 2019). This branding challenge may arguably have an extended impact on the obscurity of the destinations' brand identity which by definition should clearly define and communicate the destinations' brand. Keller (1998) and Insch (2014) notably recognise that a welldefined brand identity translates to a successful brand positioning in that it sets the boundaries of positioning by adjusting the expression and uniqueness of the place brand. Moreover, the brand identity creates its own image, distinctive properties, and positive associations and values in consumer minds with the goal of the positioning concept being an idea of differentiation (Fayvishenko, 2018; Marcu et al., 2020).

While this brand identity challenge perpetuates in brand development theories, Anholt (2010) posits a related challenge that centres on gaining the support of a heterogeneous group of destination stakeholders in designing the brand identity for large destinations. This is consistent with Inch (2014) and Saqib (2019), who proposes that the complex relationships of multiple stakeholder groups can further result in fragmented coordination and challenges in decision-making on positioning strategies. Accordingly, Pike and Mason (2011) advance that, in the event where impartial decision-making supersedes the design and implementation of the destination identity, it is critical for Destination Marketing Organisations (DMOs) to select a positioning slogan and supportive imagery which are aimed at capturing the essence of the place with a multitude of different features. While positioning must be truthful and reflect the authentic place brand, the authors stress that the challenge remains in the diversity of independent stakeholders with "different opinions, market interests and service offerings; multiple geographic markets that are heterogeneous and dynamic; a reliance on funding from public sour ces" (Pike and Mason, 2011: 170). This then has further implications for brand managers of destinations.

Arguably one of the most complex factors for destinations is that of perceptual influences of the destination brand image. Visitors often differ in their perceptions, expectations and desired satisfaction of the tourism product and the place. Likewise, the perceptions of stakeholders are considered important to destination brand positioning. This is as a result of the influence of marketing communications on stakeholders' perceived experience which convey authentic messages about the destination brand (Riad, 2016). Therefore, the complexity of destinations by reason of differences in perceptions is heightened (Saqib, 2019). Taking into account different socio-cultural backgrounds of visitors, Pike (2010) posits that visitors form different perceptions of the brand image and as a result, destination managers are expected to systematically conduct market research in order to determine any inconsistencies between the intended and perceived brand image. Chambers and McIntosh (2008) and Coz and Mowatt (2013) argue for destinations to be authentically linked to issues associated with the competitive environment and the goal of authenticity should be to achieve a competitive advantage. Consequently, the authentic reputation of the destination brand image should be promoted through a unique competitive advantage which, in essence, would contribute towards superior brand performance (Baker, 2012; Bosch and Taris, 2014; Riad, 2016). To this end, Herstein and Berger (2013) caution destinations against setting unrealistic expectations of the destinations' brand and instead suggest focussing on a brand image and identity that fits its tangible assets (such as buildings, climate, sea, reefs, roads, transportation system and facilities) as well as its intangible assets (such as history, people, and culture and spirit). Destinations are inherently different from products, thus logic dictates that the brand positioning concepts must be adapted to suit destinations so as to accommodate these differences. However, such options have not attracted much attention in the known destination marketing literature. In addition to known challenges in destination contexts, the significance in operationalising brand positioning strategies is widely acknowledged in the literature (Janiszwska and In sch, 2012; Herstein and Berger, 2013; Insch, 2014; Saqib, 2019). Studies such as those of Herstein and Berger (2013), Allameh et al. (2015), Lee et al. (2018); Wu and Cheng (2018) attempt to operationalise brand positioning in the context of a specific (sport) market. Pike's (2010) theory results in repeat visitation, brand awareness of visitor perceptions, interests, and traveling intentions. This particular study further sets out to use sport event tourism as the specific market that expresses the brand positioning to a selected destination.

\section{The role of Destination Marketing Organisations (DMOs) in brand positioning}

While the interest in applications of brand theory to practise in tourism is increasing, there is still a paucity of published research in the literature to guide DMOs on best practices that could potentially mitigate protracted complexities. However, recently Trunfio and Lucia (2018) examined best practices on how DMOs engaged stakeholders in destination brand management and marketing, thus beginning to build on and advance the current body of literature. Notwithstanding such theoretical and practical advancements, it remains unclear how the marketing and management constraints facing DMOs are alleviated as a result of the multiple complexities in destination branding. That is, the multi-attributed entities that comprise destinations, the multitude of markets and their diverse interests and perceptions, along with the heterogeneous stakeholder groups involved in decision-making, which makes the brand positioning process inherently complex.

Meanwhile, the roles of DMOs in the branding process needs more clarity. Pike (2004), Kavaratzis (2005), Pike and Mason (2011), and Rodríguez-Molina et al. (2019) generally link DMOs roles to marketing through establishing clear brand identities used to enhance the competitiveness of the destination- thus largely engaging in promotional activities. Earlier researchers, however, argue that DMOs engage in a more managerial role as they are becoming more prominent 'destination developers' by acting as catalysts and facilitators for the realisation of tourism developments (Presenza et al., 2003). As a result of this mandate and associated managerial functions, Presenza et al. (2003) dubbed the DMOs as Destination 'Management' Organisations. More recently, Morgan et al. (2012) are of the view that DMOs exist less to manage and more to coordinate, not simply to communicate with the consumer but to support the wider destination system and therefore, establishing, nurturing, and servicing partnerships between a range of stakeholders. While coordination can be viewed synonymous to management, it is not clear how these two concepts are distinct in the tourism literature and thus can be applied interchangeably. Nadalipour et al. (2018) however begin to contextualise the notion of DMOs in their study on destination sustainable competitiveness and posit that the responsibility of the DMO is to coordinate efforts to attract tourists (both business and recreational) to its geographical area (destination) without limiting their traditional role-playing in destination marketing. This then ties in with Freire (2006) who 
suggest that tourism destinations should develop a system of brand management that focuses on their brand identity with DMO's identifying a unique set of brand associations that can strategically be created and maintained.

Specifically to brand positioning, Rodríguez-Molina et al. (2019) posit that, DMOs should successfully employ high levels of message consistency across different levels of communication channels to provide alternative brand positioning strategies. As DMOs need to communicate the brand positioning to specific target markets, it is furthermore important, in destination positioning research, to explicitly identify the travel situation in which the research participant is expected to make judgements on the brand image (Pike, 2004). However, it remains unclear how DMOs contribute to the brand messaging in a unique sport event situation where another group of (sport) stakeholders are involved. Who is responsible for branding? The travel situation of interest for this paper was for sport events and more specifically, the sport spectator. While there is a clear increase in the number of (active) participants in major events, studies have also found that there is an overall significant number of (passive) participants traveling for sport (Roche et al., 2013), which may be as a result of brand perceptions/ awareness and destination attractiveness. In lure of this finding, the focus of this paper is on investigating passive participants.

\section{The influence of sport events on brand positioning}

Mega-events such as the Olympics and World Cup Games can yield particularly high levels of tourism, media coverage, prestige, and economic impacts for the host destination (Getz, 2012). While the quality of the urban development and media attention on destination brand attributes contributes positively to the destination's image and leads to favourable perceptions, it is still of concern as to how long such perceptions remain from once-off mega-events. On the contrary, small-to medium scale sport events, that occur on annual bases, have been shown to position their brand images more consistently (Kelly and Fairley, 2018). Melbourne, Australia, for example, has proven to consistently succeed in this regard by positioning an event portfolio comprised of both hallmark and major annual events and, as such, has made the destination into a fierce competitor for global brand positioning (Getz et al., 2012). The frequency in hosting major events not only enables continuity in positioning strategies but it also verifies relationships among the variables of the participants' background, the attractiveness of local sport tourism, participation motives, satisfaction, and loyalty (Chen et al., 2011).

It is for such reasons that theoretical and practical advancements have been made to event leveraging so as to employ strategies and tactics to sport event hosting to achieve desired long-term benefits such as repeat visits, future business opportunities, and lasting brand positioning (Chalip, 2014). However, while the conceptualisation of leveraging has become more prominent to mega-event hosts, recent studies have demonstrated the need for sport event leveraging in small-scale events (Kelly and Fairley, 2018; Hemmonsbey et al., 2018). Hemmonsbey et al. (2018) postulate that destination branding outcomes are nothing short of strategic and the need for event leveraging to some degree is necessary to comprehend the destination in its entirety, i.e., the perceived images through effective brand messaging of event and destination by means of competitive brand positioning. This is particularly important to secure economic development and encourage lengthening of stays and or repeat visits to the destination. Based on the premise that branding constructs in relation to identity and image plays a significant role in influencing customer satisfaction and loyalty, and ultimately lead to brand equity (Allameh et al., 2015; Wu and Cheng, 2018), it is worth researching destination branding in the context of brand positioning. This paper investigates sport as a competitive advantage and a strong motivator for brand positioning in specific (tourism) markets for host destinations. This research is practically applied to a developing, South African destination brand and it investigates the reflections of both stakeholders of sport and destin ation branding as well as sport event visitors at major events in South Africa based on variables linked to perceived quality, value, experience, satisfaction and intention to revisit. From the literature reviewed, the study sought to ask the following research questions:

RQ1: What are the brand identity and image constructs of the South African destination brand that influence stakeholder and visitor perceptions?

RQ2: To what extent does DMOs contribute to enhancing the destination brand through sport event hosting?

RQ3: How are sport events used as a vehicle to achieve/ promote brand positioning?

\section{METHODOLOGY}

This study aimed to determine the perceptions of key groups of stakeholders and event visitors on brand image constructs that address the destinations' attractions and tourism products for the purpose of establishing a favourable destination brand positioning. Research questions that led the investigation of this study were guided by the literature review and thus have informed the study's methodological processes and practices. The nature of the constructs - which are largely influenced by human perceptions (Henning et al., 2004) which in this study context are key industry stakeholders- led to the adoption of a mixed methods research approach which followed a QUAL- quant sequence. This methodological approach is appropriate when the qualitative investigation is selected as the dominant method of inquiry and the quantitative investigation subsequently acts as a support and verification of the QUAL findings (Creswell and Clark, 2011). Qualitative, face-to-face interviews of a semi-structured nature were conducted with key industry stakeholders involved in sport events, destination branding organisations, and academia. These stakeholders have specific background, training, education and/or experience in sport event hosting, marketing, strategic planning, and implementation of brand positioning and image creation strategies. The inclusion of stakeholders in academia in related areas of expertise ensured an academic, non-biased influence. More specifically, chief executive officers, senior managers, executive directors, and marketing managers at all geographical and governmental levels were considered for this research. To elicit rich and meaningful data from a wide range of stakeholders while matching the aforementioned stakeholder characteristics, a purposive sampling technique, as suggested by Jones (2015) was followed.

Table 1. List of organisations and their geographical representation Source: (Authors)

\begin{tabular}{|l|ll|}
\hline \multicolumn{1}{|c|}{ Representative organisation } & \multicolumn{1}{c|}{ Geographical representation } \\
\hline $\begin{array}{l}\text { Tourism organisations } \\
\text { (DMOs) and Destination } \\
\text { development }\end{array}$ & $\bullet$ & City of Cape Town \\
\hline $\begin{array}{l}\text { Sport event organisers and } \\
\text { marketing }\end{array}$ & $\bullet$ & Western Province \\
\hline \multirow{2}{*}{ Tour operators } & $\bullet$ & City of Cape Town \\
& $\bullet$ & Gestern Cape Government \\
\hline Academia & $\bullet$ & Cape Town \\
& $\bullet$ & Sestern Cape \\
\hline
\end{tabular}

A list of organisations with their local, provincial, or national representations are illustrated in table 1 below. To protect the individuals' identities, the study does not divulge the positions held at specific organisations, nor reveal the names of individuals interviewed.

Hagaman and Wutich (2017) reveal that larger samples sizes of between 20 and 40 interviews are necessary to reach saturation especially for identifying emerging themes. As a result, a total of 24 stakeholder interviews deemed sufficient for this study as no new themes emerged at this stage of data collection. The large quantity of data required throughout the 
quantitative phase of the current study, warrants survey questionnaires as the befitting method for data collection from event attendees (see Gratton and Jones, 2010). Respondents were targeted at major events hosted in South Africa and a random sampling of these individuals was employed by experienced fieldworkers. Randomisation ensured an autonomous selection of each respondent (Plowright, 2011). Fieldworkers were assigned particular areas at the event precinct (i.e., main entrances, water points, visitor areas, seating/ waiting areas etc.) to ensure randomness was achieved. Two major events were visited: a marathon event (the Comrades marathon - the largest one hosted in the Kwa-Zulu Natal province and South Africa) and a multidisciplinary triathlon event (the IRONMAN - hosted in Port Elizabeth, another major city in South Africa). These popular events promised a large number of participation and event attendees in particular to the international audience. The Comrades Marathon is the world's largest and oldest marathon race and places a prominent focus on South Africa as a sport destination (Turco et al., 2003). Whereas, the IRONMAN event is positioned to promote the ultimate African experience, being a scenic bike course along the Nelson Mandela Bay coastline, which has been voted Africa's best spectator course, the best run course in the world, and the second-best race venue in the world (ironmansouthafrica.com, 2018).

Guided by the proposal of Isaac and Michael (1981:193), in that "the needed samples size of a randomly selected sample from a given finite population of $\mathrm{N}$ cases", the current study has used a sample calculator to determine the N cases of both major events visited. This was calculated to achieve a $95 \%$ confidence level and at a 5\% margin of error in the results. While the researcher set out to split the sample across both events (200, respectively), by the end of the data collection, a total of 403 (200 at the Comrades Marathon and 203 at the IRONMAN) valid responses had been collected. The collection of data, therefore, achieved over $100 \%$ success rate.

All stakeholder interviews were conducted at a convenient location (usually the respondent's workplace). The interview times ranged between 45-60 minutes. Prior consent of all respondents was sought via email. Cognisant to Denzin (2010), the semi-structured interview protocol constituted a set of pre-determined questions which were developed through the literature review- however, still flexible enough to permit probing and clarifying as well as exploring specific phenomena. Questions mainly centred on destination branding strategies in relation to perceived brand image, brand identity, and brand positioning. Specific questions on the influence of sport (events) and stakeholder involvement, partnerships, and decision-making in the context of sport event hosting and destination branding were further explored. Examples of questions included; in your opinion, what are the brand characteristics/ constructs that make up the South African destination brand identity? How does brand identity and perceive image translate to brand positioning? From your experience in either sport event hosting/ tourism marketing, how do you believe your organisation contribute to the South African destination brand?

For the quantitative phase, a series of closed and open-ended questions, including 5 point Likert scale questions were developed to determined sport event attendees' profiles, their awareness and perceptions, and their satisfaction levels of the brand positioning of South Africa through established brand messages. Attendees could indicate the degree to which they agree or disagree with brand messages conveyed through the sport event, as well as whether their attendance at the event had encouraged them to, for example, retur $\mathrm{n}$ to South Africa, visit/ support other South African tourism products/ amenities, encourage others to visit, and/or change or reinforce their perception of South Africa. Primary reasons for visiting were also elicited as well as intentions to lengthen visitor stays to determine opportunities for brand positioning beyond the event phase. Questions on visitor awareness of entities who are mostly responsible for destination branding through sport event hosting in South Africa were also prompted. Paper-based questionnaires were administered by trained fieldworkers and supervised by the researcher. Informed consent was asked when the event attendees were approached, and their full anonymity was guaranteed.

The qualitative data analysis started with each interview being digitally recorded and manually transcribed verbatim using MS Word. An inductive bottom-up approach to the coding procedure was employed in determining which individual and family codes are manually assigned, categorised, and themed to a specific sentence or passage of response. There were no pre-set themes, thus the inductive (open) coding approach according to the systematic strategies of Strauss and Corbin (1990) as well as the guidelines of Miles et al. (2014) were more appropriate than a deductive top-down approach which automatically codes and themes content. The analysis thus began with open coding of interview transcripts which followed with reducing and clustering codes by grouping it into categories. From the resultant list of codes and categories, information was extracted and grouped by themes. These themes were then used in conjunction with the quantitative results which form the basis of the results section of the paper. Atlas.ti software was used to code and analyse the qualitative data, which is useful for managing and analysing copious amounts of raw data (Smit, 2002). The greatest possible effort was put forward to ensure the validity of the data that were analysed and reported through constant checking, and through comparing the voice recordings with the interview transcripts for ensuring correct meanings, interpretation, context, bias, and legitimacy. The Statistical Package for Social Sciences (SPSS) enabled researchers to perform statistical operations on the quantitative data. In preparing for data capturing, an SPSS template with the coded variables was set. Thereafter, descriptive statistics were run to indicate/ show the frequencies of the selected variables (expressed in percentages and graphs). The questionnaire was piloted, and the results were analysed to assess all factors prior to the actual data collection. The results gleaned were continuously assessed throughout the research process to maintain the validity of the study.

Results from the profiling of sport event attendees show that the respondents who participated in the study are presented as follows. The demographic profile in terms of racial and age backgrounds shows that, most of the respondents were predominantly white/ Caucasians who ranged between the ages of 26 and 45 years old, (i.e. young adults). The gender composition of the sample was almost equally divided between males $(51.4 \%)$ and females $(48.6 \%)$. An average monthly disposable income, ranging between R25 $001-\mathrm{R} 30$ 001 per month, was calculated across respondents at both events. When converted to US Dollars, this equates to roughly $\$ 1,649$ - $\$ 2,039$. A geographic profile of the origin of respondents show that $40.9 \%$ of the event attendees were from South Africa, whilst $59.1 \%$ of respondents represented other countries. An analysis of the international attendees shows that the majority of them were from the USA (7.8\%), Germany (5.4\%), the UK (5.1\%), Australia $(4.7 \%)$, Spain $(4.4 \%)$, Canada (3.7\%), and Argentina (3.0\%) with the rest of the international attendees representing a number of other countries.

\section{RESULTS}

While participant quotes are used to illustrate their responses, in order to protect their identities, a number is assigned to each respondent (e.g., R1, R2, R3, etc.), which bear no significance to their title or positions. Where necessary- to express a response given by specific respondents-, the representative organisation is used as a frame of reference. The respondents discussed the global brand identity of South Africa, brand messages influencing perceptions, and the challenges facing brand managers when positioning an authentic South African brand.

\section{Global brand identity of South Africa}

Resulting from the brand logo and the subsequent messaging emanating from the logo design and promotional campaigns, respondents mentioned that the South African destination's brand identity is globally positioned. For instance,

South Africa is a prime destination for international tourism through its brand identity trademark [R2]. 
The South African brand identity upholds a strong global appeal that attracts international tourism markets... I mean, the flag is globally recognisable and it is in our logo [R9].

Our brand is identified in our logo design and it extends to a large [international] audience [R8].

One of the most intelligent logos ever used in South Africa was the 'Proudly South African' logo whish was an endorsement sticker and campaign on the South African destination products [RI].

Distinguishing the brand identity, unique features of the South African brand were mentioned to contribute to this brand positioning. Notably, intangible, experiential elements linked to nature and wildlife were mentioned. For example,

South Africa is a global brand which is still associated with nature and wildlife. The destination is still an animal attraction and it attracts people here. [R10].

Emphasising this point, a respondent in sport event organising articulated the unique brand compared to elsewhere in the world- "[South African cities] offer world-class conferencing and sport, and yet, in a few hours, you can be in a [i.e. the] bush experiencing the big five [i.e. Africa's largest and most dangerous mammals], which you simply can't do anywhere [else] in the world" [R4].

In relation to sport, respondents mentioned that the event is a pull factor to position the primary identity in the minds of consumers. Illustrating practical examples of sport, respondents in sport event marketing expressed the following points,

The Cape Town Cycle Tour as an example, [for] domestic and international visitors, it isn 't just coming to a bicycle race in Cape Town. The sport event is only the hook. It is more like, "We are going to Cape Town, why don't we stop in Johannesburg on our way back [home] and spend a week at the Kruger National Park". It is about leveraging those opportunities [R4].

Our event is [there] to attract fans, it is to get people to our country, to experience this destination. But the event makes it so much accessible to come and enjoy the unique countries landscape [R17].

Stellenbosch [a region in the Western Cape] is a global destination for especially mountain bikers. We host our [mountain bike] event and the World Championships in the Western Cape. Athletes are not going to Cyprus or Spain to train or compete, they are choosing Stellenbosch, and it's amazing for the brand's distinctiveness [R8].

Furthermore, stakeholders in provincial government and sport and recreation mentioned the value of the brand identity and more importantly that the value results in the "lengthening of visitor stays" [R4] as well as the sustenance of tourism operations, such as"experiencing South Africa's accommodation, catering, hotels, attractions, and sport at large" [R6].

Sport event attendees were asked what their main reasons/ motivation were for their visit to the host destination so as to es tablish whether the event is in fact a pull factor for brand positioning (see Table 2 below). A significant amount (81.5\%) of respondents indicated 'the sport event' as their main reason. Second to this, (8.1\%) indicated that 'business' was the main reason. Whereas 'general tourism/ sightseeing' and 'visiting friends and family' received equal indications (5.2\%).

Table 2. Main reason for respondents' visit $(n=403$, in $\%)$

\begin{tabular}{|l|c|}
\hline Reason & \% \\
\hline To participate in the event & 81.5 \\
\hline General tourism/sightseeing & 5.2 \\
\hline Business & 8.1 \\
\hline To visit friends and family & 5.2 \\
\hline
\end{tabular}

Further questions regarding pre- and post- event stays were probed to elucidate their entire stay in the destination. When asked whether the attendees have extended their stay after the event, $51.6 \%$ indicated 'yes' and $48.4 \%$ indicated 'no'. From the indicated 'yes' responses, $41.9 \%$ of the respondents specified their intentions to extend their stays between 1 to 2 days after the event phase. $30.1 \%$ have specified their intentions to about 3 to 5 days, and a notable number of respondents (27.9\%) have specified to extend their stays for more than 5 days post event. Regarding pre-event stays, most of the sport event attendees' arrivals were 3 to 5 days before the event (45.7\%), followed by the percentage of $39.7 \% 1$ to 2 days before, with only $14.6 \%$ indicating more than 5 days before the event.

\section{Brand messages influencing perceptions}

The following appeared to be clear brand messages from multiple stakeholder responses.

\section{Value for money:}

This 'good value for money' is why we [i.e. South Africa] have been voted number one tourism destination in the world for five consecutive years through different media groups and publications [R3].

Our currency is shockingly weak, which is not actually good but in saying that, it is cheap for international visitors [R4].

South Africa is well perceived as one of the 'cheapest' global destinations to visit. The [South African] Rand compared to other European countries...even the dollar... it is much cheaper [affordable] [R11].

\section{Welcoming/ friendly host:}

South Africans are welcoming and friendly as a people so visitors will feel at home [R9].

In terms of the friendliness, people remember that, they will go back [and] the tourism experience is heightened [R3].

Brand messages sent is [that] we are a friendly nation and we are hospitable. We want to welcome you. We need to be welcoming and that is what tourism is all about [R24].

So the friendliness and willingness to help because first impressions last [R15].

\section{Good climate/ natural features:}

South Africa offers good qualities in terms of its climate. We are a prime destination to market this country and enjoy the benefits of that [R7].

One can argue that the South African climate is a big benefit as it attract year round sport and events [R10].

South Africa boast a good climate with attractions such as the mountains, the landscape, and the beaches. Durban has beach attractions, coastlines, so does PE [Port Elizabeth] and Cape Town, our other cities offer great offerings as well, we have the wine farms in Stellenbosch... [R1].

Notably, respondents in local and national event organising referred to more tangible make-ups of South African in its history and heritage and they believed that sport can be used in conjunction with such brand messages to position an all-encompassing destination brand image. 
So when people think about South Africa, from a sport perspective they think about the name, 'Nelson Mandela', 'Robin Island'. We [have] unique characteristics [and] we are now able to show that. The Robin Island swim race, now that iconic history and heritage, that contributes conceptually. This race is in its $9^{\text {th }}$ year and they run 27 kilometres (for every year that Madiba was in prison) [R9].

Tshwane for example, it has got the historical Voortrekker Monument [raised to commemorate the Voortrekkers who left the Cape Colony] - which is a prime attraction for tourists. The Tshwane Golf Open has used and promote this and in fact, the positioning statementsaying 'it is not all about golf' [R6].

Adversely, social imperatives such as safety and security, and health and education were mentioned to negatively impact the destination brand. While it was argued respondents that these issues are largely perpetuated in the international media, it is believed that these issues are real challenges that need more prioritisation over large event budgets. For example,

You would be surprised the international media coverage you get about the safety and security- those are key barriers that we work with. [R5].

Social issues are often not prioritised as it should similar to other imperatives such as hosting large scale sporting tournaments [R12].

We have a safety and security problem, so to put the billions of Rands [in]to pitching for major events, it is taking out of housing, education and health, so this needs to be prioritised [R4].

From a tourism perspective, a respondent in local tourism management enunciated that, the negative ones are the safety and security because people experience those [RI].

Results of sport event attendees on perceived brand messages largely correspond with stakeholder sentiments. Respondents were asked whether they strongly disagree to strongly agree that the South African brand conveyed certain brand messages though sp ort event hosting. Table 3 below illustrates that respondents strongly agreed on South Africa 'being a capable host of sport and events' (62.8\%) as the main brand messages. Thereafter, 'being a welcoming host to its visitors' (61.8\%) were almost similarly perceived. A close indication for 'being both friendly and scenic' (59.5\%) and an almost equally close indication of 'being diverse' (56.6\%), 'being a competitive destination for major sport event hosting' (56.4\%) and 'having a good climate' (54.1\%) were indicated. Albeit under the 50 percent mark, 'rich heritage' $(43.7 \%)$ were also viewed favourably. On the contrary and not surprising are variables linked to 'political stability' $(35.3 \%)$ and 'safety' (30.4\%) which scored the least favourable and or neutral. Consistent with the neutral responses are 'busines opportunities' although the agreed column obtained more responses $(34.2 \%)$ to the business variable.

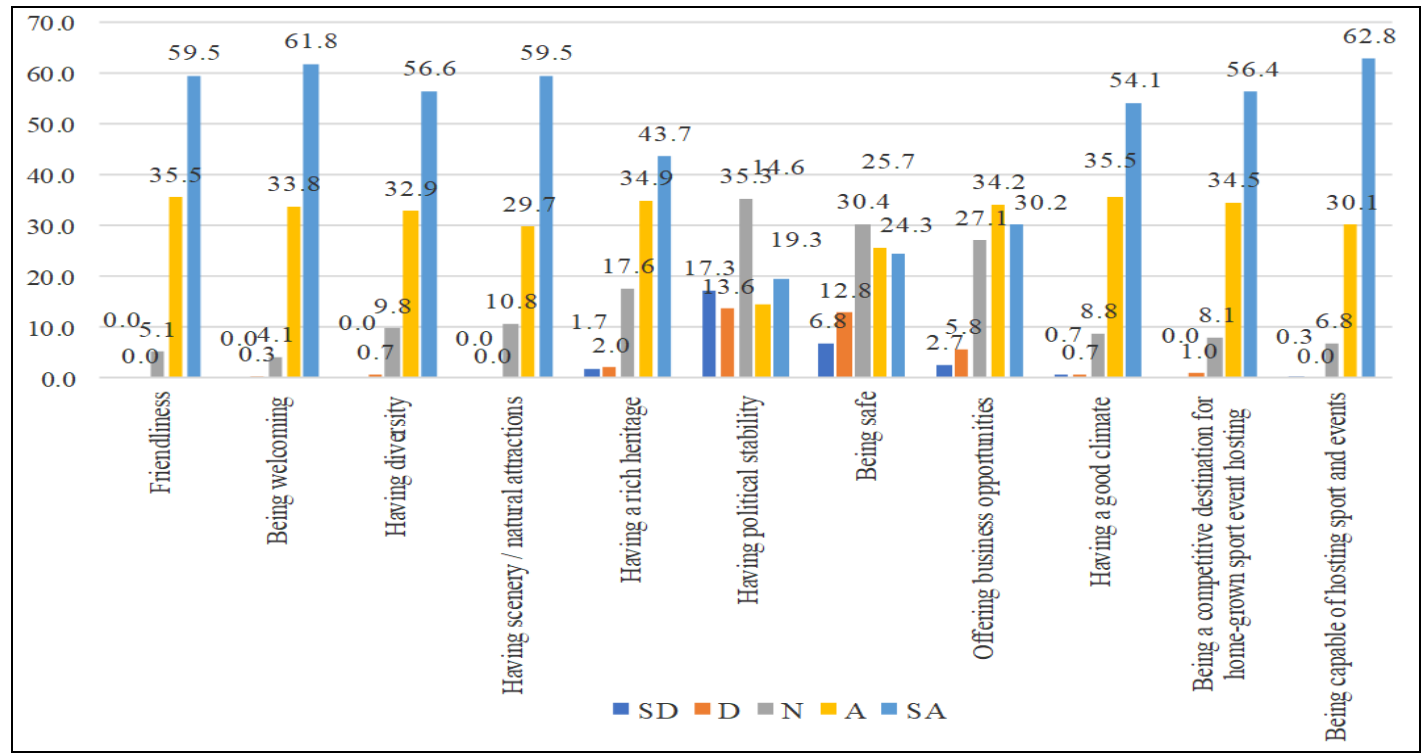

Figure 1. The brand messages of South Africa conveyed through sport event hosting $(n=403$, in $\%)$

Respondents were further asked whether their attendance at the sport event had encouraged them to perceive, to promote, or to support the South African destination brand positioning, by referring to key variables. The results in Table 4 show that the subjects were strongly agreeing with; 'visiting/encouraging others to revisit the host city' (57.8\%); 'returning to the host city to spectate/participate in the event again' (54.1\%); 'visiting other South African cities/provinces' (52.4\%); 'supporting local South African business' (53.6\%); and 'promoting the host city to family and friends' $(54.6 \%)$. Albeit not above $50 \%$, 'spectating/participating in similar events in other South African cities' $(47.3 \%)$ was also strongly agreed upon across the entire subject group. Almost split between agreeing (37.2\%) and strongly agreeing $(44.3 \%)$, respondents believed that 'the event changed/reinforced their perceptions of the host city'.

Challenges facing brand managers in South Africa when positioning an authentic South African brand

Stakeholders mentioned clear challenges to the South African brand management and promotion that are believed to impede the brand positioning. These challenges are linked to financial contributions as well as marketing related. For example,

Investment related: Events need to be driving international participation, but it can only drive it gets the support of the national role players. They say events are successful provincially, I would say 'yes', but [the event] can't give you a return if [national government] are not helping [R4].

We are marketing South Africa as a destination. The challenge events have, is that it gets little to no support from national tourism, trade and industry, and economic development, hence event organisers are limited to promote their own event [R8].

From a national tourism perspective, a respondent addressed this investment challenge by admitting to a desire to commit to sport event branding, however, the infancy of a sport strategy at a national tourism level has not made this possible to the full extent. For example, 
So there has never been someone driving sport at SA tourism before, again it's a huge organisation. We have not been able to firm because of not having a full-on strategy just yet, it's hard to commit [R20].

This respondent further mentioned the expectations of sport event organisers that does not meet the broader sport tourism sector. For instance,

Most event organisers think it's like they give us millions and we slap on a logo and that is fine. We say no, we want our ecosystem to benefit, our graded establishments, our tour guides, our tour operators, and cites [R20].

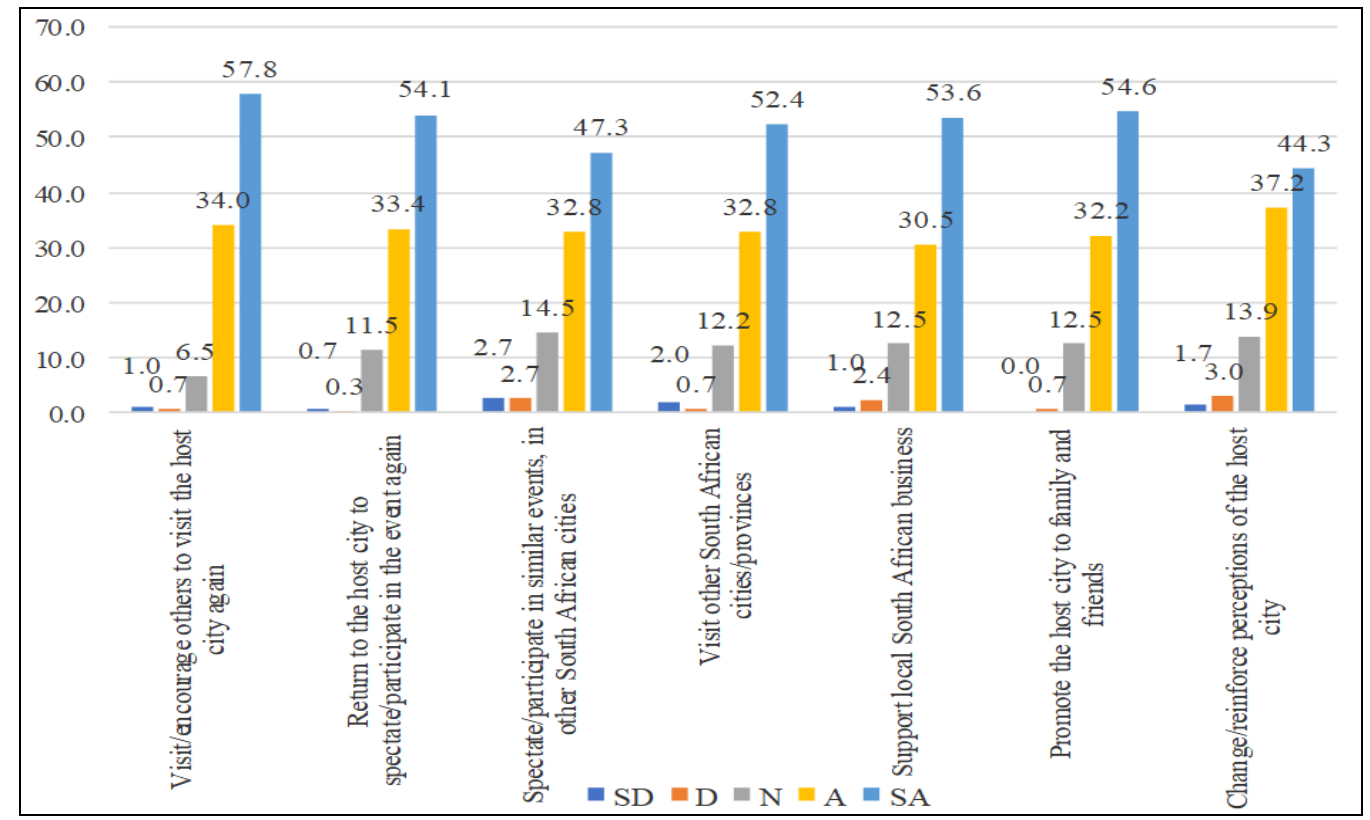

Figure 2. Respondents' attendance at event encouraged them to... $(n=403$, in $\%)$

Marketing/promotional related: Destination branding for South Africa has become a little bit disjointed. All the components that makeup South Africa are all competing with each other and there is no overarching grace of selling the South African brand [R 12].

It is the collective responsibility of all entities to promote South Africa to visitors. It is imperative to form those partnerships between sport and tourism- across the board- but that is unfortunately not happening, not in the best functioning way at least [R3].

If government see that if they are able to assist funding and promoting events to niche markets, which they couldn't buy their way into, then there is benefit for them in marketing the country [R4].

When asking event attendees who they believe were responsible for branding/ promoting South Africa during sport event hosting, the results in Table 5 show that $33.5 \%$ of the sport event organisers were believed to be the most responsible for the destination branding practices concerned. Closely followed was the government, with $32.7 \%$. Private investment companies/sport brand sponsors were deemed responsible for destination branding by $18.0 \%$ of the respondents, with the community and tour operating companies, with $8.1 \%$ and $7.7 \%$, respectively, being perceived to be the least responsible for destination branding practices.

Table 3. Which entities are most responsible for destination branding practices concerning the hosting of sport events $(n=403$, in $\%)$

\begin{tabular}{|l|c|}
\hline Entity & $\mathbf{\%}$ \\
\hline Government & 32.7 \\
\hline Sport event organisers & 33.5 \\
\hline Tour operating companies & 7.7 \\
\hline Private investment companies / sport brand sponsors & 18.0 \\
\hline Community & 8.1 \\
\hline
\end{tabular}

\section{DISCUSSION AND IMPLICATIONS}

From the current study's findings, it is apparent that the South African brand distinctiveness lies in logo and trademark design of the destination's brand identity. This can be distinguished by the imagery of the country's flag and through promotional campaigns that express the uniqueness of the brand.

Such findings are consistent with past studies that recognise the translation of a well-defined brand identity is to express the uniqueness of a place brand, as well as to create its own image, distinctive properties, positive associations, and values in consumer minds, with brand positioning being the idea of differentiation (Keller, 1998; Insch, 2014; Fayvishenko, 2018). While diverse tourism experiences which include elements of wildlife and diversity positively promotes the authentic destination brand, it is, however, unclear how such features are definitively incorporated in the brand identity and subsequent positioning. Conversely, from a sport event perspective, such elements are not only considered but are inadvertently used to attract visitors. Thus, studies arguing the importance of a clear value proposition (in this case the sport event), so as to augment brand distinctiveness are supported (Kapferer, 2012). However, supporting the opposite, the results from sport event visitors show that the majority of event visitors $(81.5 \%)$ indicated the actual event as their main reasons for visiting the host destination. A shockingly low number of attendees (5.2\%) indicated general tourism/ sightseeing. This then begs the question as to how effectively the event is used to stimulate ancillary intentions and, to which extent destination attractions such as wildlife influences travellers' decisions? A fair indication (27.9\%) to post-visitor stays were indicated for longer than 5 days after the event which show potential interest from event visitors in tourism products and destination offerings. What is more, variables relating to repeat visits/ revisiting intentions and promoting the destination to others scored favourably (above 50\%) across sport event visitors which further translate to brand equity/ value (Tran et al., 2020; Chi et al., 2020). For the destination to fully realise (long-term) benefits from sport tourism, secondary motivations thus need to be stimulated. It might thus be feasible for South African sport and destination brand stakeholders to employ strategic branding practices through leveraging major sport as posited by Chalip (2014).

Chambers and McIntosh (2008) and Coz and Mowatt (2013) suggest that the goal of brand authenticity is to achieve competitive advantage. Herstein and Berger (2013) thus suggest destinations focus on a brand that fits its tangible and intangible assets so as to achieve competitive positioning. Correspondingly, the study's results on perceived brand messages show congruence between stakeholder and visitor 
perceptions on a destination brand image that convey both tangible and intangible features. Beyond these features, the current study adds perceptions of efficiency and competency to host major sport which help achieve a competitive positioning as event attendees positively perceived 'being a capable host of sport and events' (62.8\%) and 'being a competitive destination for major sport event hosting' (56.4\%). Therefore, advancing the branding theory on branding perceptions by including competitive brand features in a unique sporting environment. While social challenges are believed to persist towards the South African brand image, it is in the management of such challenges to mitigate the effects thereof on the sport tourism experience. Congruent to a remaining challenge in the destination branding literature is the complexity in the multiple stakeholder groups, their contributory roles, and their exceeding expectations.

The current study elucidates the roles of branding organisations consistent with Nadalipour et al. (2018) - according to marketing and management functions to the promotions of brand messages and the coordination of branding partners. This is despite other researchers distinguishing these functions (i.e. Pike, 2004; Kavaratzis, 2005; Pike and Mason, 2011; Rodríguez-Molina et al., 2019). Largely from a national tourism standpoint, investment and marketing-related challenges seem to impede on the consistency and efficacy of brand management and marketing where the destination and the event are left to promote themselves. Relatedly, the absence and infancy of a sport strategy by national tourism organisations further impede the destination brand positioning to specific (niche) markets. Although a definitive view into stakeholder responsibilities and expectations for destination branding through sport is unclear, both public (government) organisations and private (sport organisers) are deemed in charge of sport brand positioning. The implication for stakeholders is thus to collectively coordinate their mandates and set realistic expectations between sport event organisers and tourism organisations to cover the scope of each stakeholder's mandate while benefiting the broader tourism sector. From a theoretical perspective, destination brand positioning literature is commonly linked to brand identity, image and equity constructs (Keller, 1998; Fuchs and Diamantopoulos, 2012; Insch, 2014). However, for the most part, such constructs remain notional. Yet, some researchers acknowledge that the adoption of value propositions that help define brand identities and help distinguish brand images which are consequently considered for brand positioning (Funch and Diamantopoulos, 2010). It is previously posited that the innate hosting and participating nature of sport events distinguishes sport as value propositions for destination brand (re)positioning (Rein and Shields, 2007). The current study thus explores value proposition in the context of sport and challenges such notional constructs as well as advances extant brand positioning theories. Furthermore, the pragmatic investigation of this study provides new empirical evidence on the unique destination brand positioning in the context of sport.

\section{CONCLUSIONS AND FUTURE RESEARCH}

Destination brand positioning is evident in clear and established brand identities. Beyond promotional activities, destination marketers and managers need to ensure consistent brand image perceptions linked to intangible, tangible and competitive destination features. Sport can be a positive value proposition to establish the destination brand in the minds of a unique niche market, however, it is not without the proper investment and commitment from all sport and branding stakeholders to effectively achieve desired results.

While this study used sport events as the central point for examining destination brand positioning, it acknowledges that sport tourism extends beyond events to include a number of other industries such as sport business and conferences. To extend the current study's scope, it is therefore recommended that further research incorporates a multidimensional perspective of sport tourist s. Moreover, the tourism industry extends beyond sport, and especially with secondary brand images mentioned, it is viable to extend the current study's context to include events with a different focus (such as cultural, social, or historical).

\section{REFERENCES}

Allameh, S.M., Pool, J.K., Jaberi, A., Salehzadeh, R., \& Asadi, H. (2015). Factors influencing sport tourists' revisit intentions. Asia Pacific Journal of Marketing and Logistics, 27 (2), 191-207. https://doi.org/10.1108/APJML-12-2013-0159

Anholt, S. (2010). Places: Identity, Image and Reputation. Basingstoke, MacMillan: Hampshire.

Baker, B. (2012). Destination branding for small cities, 2nd edition, Creative Leap Books, Portland, OR.

Bosch, R.V.D., \& Taris, T.W. (2014). The authentic worker's well-being and performance: The relationship between authenticity at work, well-being, and work outcomes. The Journal of Psychology, 148, 659-681. https://doi.org/10.1080/00223980.2013.820684

Bregoli, I. (2012). Effects of DMO coordination on destination brand identity: a mixed methods study on the city of Edinburgh. Journal of Travel Research, 52 (2), 212-224. https://doi.org/10.1177/0047287512461566

Brooksbank, R. (1994). The anatomy of marketing positioning strategy. Marketing Intelligence \& Planning, 12 (4), 10-14. https://doi.org/10.1108/02634509410060695

Cai, L.A. (2002). Cooperative branding for rural destinations. Annals of Tourism Research, 29(3), 720-742. https://doi.org/10.1016/S0160-7383(01)00080-9

Chacko, H.E., \& Marcell, M.H. (2008). Repositioning a tourism destination: The case of New Orleans after hurricane Katrina. Journal of Travel \& Tourism Marketing, 23 (2-4), 223-235. https://doi.org/10.1300/J073v23n02_17

Chalip, L. (2014). From legacy to leverage. In Grix, J. (Ed.). Leveraging legacies from sports mega-events: Concepts and cases, Palgrave Macmillan: Basingstoke, pp. 2-12.

Chambers, D., \& McIntosh, B. (2008). Using authenticity to achieve competitive advantage in medical tourism in the English-speaking Caribbean. Third World Quarterly, 29, 919-937. https://doi.org/10.1080/01436590802106056

Chen, K.C., Lin, Z.P., \& Cheng, Y.L. (2011). Sports tourist's perceptions toward the 2009 Taipei deaflympics: A structural equation modeling approach. 2011 IEEE International Summer Conference of Asia Pacific Business Innovation and Technology Management, IEEE, pp.163-167.

Chi, H., Huang, K., \& Nguyen H.K. (2020). Elements of destination brand equity and destination familiarity regarding travel intention. Journal of Retailing and Consumer Services, 52. https://doi.org/10.1016/j.jretconser.2018.12.012

Crawford, C., \& Di Benedetto, C. (2008). New Products Management, 1st edition, McGraw-Hill Education, New York, NY.

Creswell, J.W., \& Clark, V.L.P. (2011). Designing and conducting mixed methods research, 2nd edition, SAGE, Los Angeles, CA.

Daye, M. (2010). Challenges and prospects of differentiating destination brands: the case of the Dutch Caribbean Islands. Journal of Travel \& Tourism Marketing, 27 (1), 1-13. https://doi.org/10.1080/10548400903534725

Denzin, N.K. (2010). Moments, mixed methods and paradigm dialogs. Qualitative Inquiry, 16, 419-427. https://doi.org/10.1177/1077800410364608

Fayvishenko, D. (2018). Formation of brand positioning strategy. Baltic Journal of Economic Studies, 4 (2), 245-248. https://doi.org/10.30525/2256$0742 / 2018-4-2-245-248$

Freire, J.R. (2006). Other tourists: A critical factor for a geo-brand-building process. Place Branding, 2 (1), 68-83. https://doi.org/10.1057/palgrave.pb.5990046

Fuchs, C., \& Diamantopoulos, A. (2010). Evaluating the effectiveness of brand-positioning strategies from a consumer perspective. European Journal of Marketing, 44 (11/12), 1763-1786. https://doi.org/10.1108/03090561011079873

Fuchs, C., \& Diamantopoulos, A. (2012). Customer-perceived positioning effectiveness: Conceptualization, operationalization, and implications for new product managers. Journal of Product Innovation Management, 29 (2), 229-244. https://doi.org/10.1111/j.1540-5885.2011.00892.x

Gratton, C., \& Jones, I. (2010), Research methods for sport studies, 2nd edition, Routledge, London.

Getz, D. (2012). Sport event tourism: planning development and Marketing. In Hudson, S. (Ed.). Sport and adventure tourism, pp. $49-88$.

Getz, D., Svensson, B., Peterssen, R., \& Gunnervall, A. (2012). Hallmark events: Definition and planning process. International Journal of Event Management Research, 7 (1/2), 47-67.

Govers, R., \& Go, F. (2009). Place branding: Glocal, virtual and physical identities, constructed, imagined and experienced. Palgrave Macmillan: Basingstoke.

Hagaman, A.K., \& Wutich, A. (2017). How many interviews are enough to identify metathemes in multisited and cross-cultural research? Another perspective on Guest, Bunce, and Johnson's (2006) landmark study. Field Methods, 29(1), 23-41. 
Hemmonsbey, J., \& Tichaawa, T.M. (2020). Brand messages that influence the sport tourism experience: the case of South Africa. Journal of Sport \& Tourism, 24(3), 177-194, https://doi.org/10.1080/14775085.2020.1822200

Hemmonsbey, J., \& Tichaawa, T.M. (2019a). Using non-mega events for destination branding: A stakeholder perspective. GeoJournal of Tourism and Geosites, 24(1), 252-266. https://doi.org/10.30892/gtg.24120-357

Hemmonsbey, J., \& Tichaawa, T.M. (2019b). Strategic planning of sport tourism events on destination brands: Examining the role of home-grown sport. Geojournal of Tourism and Geosites, 26(3), 794-807. https://doi.org/10.30892/gtg.26310-398

Hemmonsbey, J., \& Knott, B. (2016). Branding an African city through sport: The role of stakeholder engagement. African Journal of Hospitality, Tourism and Leisure, 5(3), 1-14.

Hemmonsbey, J., Tichaawa, T., \& Knott, B. (2018). Conceptual framework for strategic destination branding through leveraging home-grown sport events. South African Journal for Research in Sport, Physical Education and Recreation, 40(2), 81-98.

Henning, E., van Rensburg, W., \& Smit, B. (2004). Finding your way in qualitative research. Pretoria: Van Schaik.

Herstein, R., \& Berger, R. (2013). Much more than sports: sports events as stimuli for city re-branding. Journal of Business Strategy, 34(2), 38-44. https://doi.org/10.1108/02756661311310440

Ibrahim, E.E. \& Gill, J. (2005). A positioning strategy for a tourist destination, based on analysis of customers' perceptions and satisfactions. Marketing intelligence \& planning, 23(2),172-188. https://doi.org/10.1108/JTA-05-2019-0019

Indrie, L., Zlatev, Z., Ilieva, J., Ilies, D.C., Sturza, A., Dochia, M., Gozner, M., Herman, G., Caciora, T. (2020). Implementation of image processing techniques as a tool for form analysis of Romanian folk elements, Industria textila, 71(5), 492-498. http://doi.org/10.35530/IT.071.05.1690

Insch, A. (2014). Positioning cities: Innovative and sustainable strategies for city development and transformation. Place branding and public diplomacy, 10 (4), 249-252. https://doi.org/10.1057/pb.2014.30

Isaac, S., \& Michael, W.B. (1981). Handbook in research and evaluation, Edits, San Diego, CA.

Jones, I. (2015). Research methods for sports studies, $3^{\text {rd }}$ edition, Routledge, London.

Kapferer, J.N. (2012). The new strategic brand management: Advanced insights and strategic thinking. Kogan page publishers.

Kavaratzis, M. (2005). Place branding: A review of trends and conceptual models. The marketing review, 5(4), 329-342. https://doi.org/10.1362/146934705775186854

Keller, K.L. (1998). Strategic Brand Management in: Building, Measuring, and Managing Brand Equity, Prentice Hall, New Jersey.

Kelly, D.M., \& Fairley, S. (2018). What about the event? How do tourism leveraging strategies affect small-scale events? Tourism Management, 64, 335-345. https://doi.org/10.1016/j.tourman.2017.09.009

Klein, K., Völckner, F., Hernán A. Bruno, H.A., Sattler, H., \& Bruno, P. (2019). Brand positioning based on brand image-country image fit. Marketing Science, 38 (3), 516-538. https://doi.org/10.1287/mksc.2019.1151

Konecnik, M., \& Go, F. (2008). Tourism destination brand identity: The case of Slovenia. Journal of Brand Management, 15, 177-189. https://doi.org/10.1057/palgrave.bm.2550114

Kotsi, F., \& Pike, S. (2020). Destination brand positioning theme development based on consumers' personal values. Journal of Hospitality and Tourism Research. Available from: https://eprints.qut.edu.au/200054/

Lee, J.L., Kim, Y., \& Won, J. (2018). Sports brand positioning. International Journal of Sports Marketing and Sponsorship, 19(4), 450-471. https://doi.org/10.1108/IJSMS-03-2017-0018

Maennig, W. (2019). Major Events: Economic Impact. In Downward, P., Frick, B., Humphreys, B.R., Pawlowski, T., Ruseski, J.E., \& Soebbing, B.P. (Eds.). The SAGE Handbook of Sports Economics, pp.356.

Miles, M., Huberman, A., \& Saldaña, J. (2014). Qualitative data analysis: A methods sourcebook. 3rd ed. SAGE: London.

Marcu, F., Ilies, D.C., Wendt, J., Indrie, L., Ilies, A., Burta, L., Caciora, T., Herman, G.V., Todoran, A., Baias, S., Albu, A., \& Gozner, M. (2020). Investigations Regarding the Biodegradation of Cultural Heritage. Case Study of Traditional Embroidered Peasent Shirt (Maramures, Romania). Biothnological Letter, 25(2), 1362-1368. https://www.e-repository.org/rbl/vol.25/iss.2/8.pdf

Morgan, N., Hastings, E., \& Pritchard, A. (2012). Developing a new DMO marketing evaluation framework: The case of Visit Wales. Journal of Vacation Marketing, 18(1), 73-89. https://doi.org/10.1177/1356766711432225

Nadalipour, Z., Khoshkhoo, M.H.I., \& Eftekhari, A.R. (2019). An integrated model of destination sustainable competitiveness. Competitiveness Review: An International Business Journal, 29(4), 314-335. https://doi.org/10.1108/CR-12-2017-0086

Pike, S., \& Mason, R. (2011). Destination competitiveness through the lens of brand positioning: the case of Australia's Sunshine Coast. Current Issues in Tourism, 14(2), 169-182. https://doi.org/10.1080/13683501003797523

Pike, S. (2010). Destination branding case study: Tracking brand equity for an emerging destination between 2003 and $2007 . \quad$ Journal of Hospitality \& Tourism Research, 34(1), 124-139. https://doi.org/10.1177/1096348009349820

Pike, S.D. (2004). Destination brand positioning slogans-towards the development of a set of accountability criteria. Acta Turistica, $16(2)$, $102-124$.

Pike, S., \& Page, S. (2014). Destination marketing organisations and destination marketing: a narrative analysis of the literature. Tourism Management, 41, 202-227. https://doi.org/10.1016/j.tourman.2013.09.009

Plowright, D. (2011). Using mixed methods: Frameworks for an integrated methodology, SAGE, London.

Presenza, A., Sheehan, L., \& Ritchie, J.B. (2005). Towards a model of the roles and activities of destination management organizations. Journal of Hospitality, Tourism and Leisure Science, 3(1), 1-16.

Raid, S. (2016). Branding destination image: A stakeholder causal scope analysis for internationalisation of destinations. Tourism Planning \& Development, 13(2), 140-153. https://doi.org/10.1080/21568316.2015.1096299

Rein, I., \& Shields, B. (2007). Place branding sports: Strategies for differentiating emerging, transitional, negatively viewed and newly industrialised nations. Journal of Place Branding and Public Diplomacy, 3(1), 73-85. https://doi.org/10.1057/palgrave.pb.6000049

Rodríguez-Molina, M.A., Frías-Jamilena, D.M., Del Barrio-García, S., \& Castañeda-García, J.A. (2019). Destination brand equity-formation: Positioning by tourism type and message consistency. Journal of Destination Marketing \& Management, 12, 114-124. https://doi.org/10.1016/j.jdmm.2019.03.010

Roche, S., Spake, D.F., \& Joseph, M. (2013). A model of sporting event tourism as economic development. Sport, Business and Management: An International Journal, 3(2), 147- 157. https://doi.org/10.1108/20426781311325078

Saqib, N. (2019). A positioning strategy for a tourist destination, based on analysis of customers' perceptions and satisfactions: A case of Kashmir, India. Journal of Tourism Analysis: Revista de Análisis Turístico, 26(2), 131-151. https://doi.org/10.1108/JTA-05-2019-0019

Smit, B. (2002). Atlas.ti for qualitative data analysis. Perspectives in Education, 20(3), 65-75.

Strauss, A., \& Corbin, J. (1990). Basics of qualitative research: Grounded theory procedures and techniques. 2nd ed. SAGE: London.

Tasci, A.D., \& Gartner, W.C. (2007). Destination image and its functional relationships. Journal of travel research, 45(4), 413-425.

Tran, P.K.T., Nguyen, V.K., \& Tran, V.T. (2020). Brand equity and customer satisfaction: a comparative analysis of international and domestic tourists in Vietnam. Journal of Product \& Brand Management, https://doi.org/10.1108/JPBM-08-2019-2540

Trunfio, M., \& Lucia, M.D. (2019). Engaging destination stakeholders in the digital era: The best practice of Italian regional DMOs. Journal of Hospitality \& Tourism Research, 43(3), 349-373. https://doi.org/10.1177/1096348018807293

Turco, D.M., Swart, K., Bob, U., \& Moodley, V. (2003). Socio-economic impacts of sport tourism in Durban Unicity, South Africa. Journal of Sport Tourism, 8(4), 223-239. https://doi.org/10.1080/1477508032000161537

Wu, H.C., \& Cheng, C.C. (2018). What drives spectators' experiential loyalty? A case study of the Olympic Football Tournament Rio 2016. Asia Pacific Journal of Marketing and Logistics, 30(4), 837-866. https://doi.org/10.1108/APJML-08-2017-0174

Zhang, L., \& Zhao, S.X. (2009). City branding and the Olympic effect: A case study of Beijing. Cities, 26(5), 245-254. https://doi.org/10.1016/j.cities.2009.05.002

*** IRONMAN South Africa (2018). About the event. Available from: http://eu.ironman.com/triathlon/events/emea/ironman/south-africa.aspx\#axzz5a2tCgbMk 